\title{
Binding of reactive organophosphate by oximes via hydrogen bond
}

\author{
ANDREA PAPPALARDO, MARIA E AMATO, FRANCESCO P BALLISTRERI, \\ VALENTINA LA PAGLIA FRAGOLA, GAETANO A TOMASELLI, ROSA MARIA TOSCANO \\ and GIUSEPPE TRUSSO SFRAZZETTO* \\ Dipartimento di Scienze Chimiche, Università di Catania, viale A Doria 6, 95125 Catania, Italy \\ e-mail: giuseppe.trusso@unict.it
}

MS received 17 December 2012; revised 1 March 2013; accepted 5 April 2013

\begin{abstract}
In this contribution, the ability of simple oximes to bind a well-known nerve agent simulant (dimethylmethylphosphonate, DMMP) via hydrogen bond is reported. UV/Vis measurements indicate the formation of 1:1 complexes. ${ }^{1} \mathrm{H}-,{ }^{31} \mathrm{P}-\mathrm{NMR}$ titrations and T-ROESY experiments confirm that oximes bind the organophosphate via hydrogen bond.
\end{abstract}

Keywords. Nerve agents; oximes; hydrogen bond; organophosphate stimulant.

\section{Introduction}

Chemical warfare agents (CWAs) are classified into several groups; i.e., nerve agents, asphyxiant/blood agents, vesicant agents, pulmonary agents, lachrymatory agents, incapacitating agents and cytotoxic proteins. ${ }^{1,2}$ All these nerve agents are among the most dangerous of chemical warfare species. In particular, nerve agents are a family of highly toxic phosphoric acid esters, structurally related to the larger family of organophosphate compounds (figure 1). Deadly nerve agents have rapid and severe effects on human and animal health, either in gas, aerosol or liquid forms. ${ }^{3,4}$ Their effect is mainly due to their ability to inhibit the action of acetylcholineesterase (AChE), a critical central nervous system enzyme.

Ease of production and extreme toxicity of organophosphorous nerve agents underline the need to detect these odourless and colourless chemicals. As a consequence, intense research and many efforts have been directed towards developing sensitive and selective systems for detection of these harmful compounds. ${ }^{5-10}$ A variety of detection methods for the CWAs has been developed, including enzymatic assays, ${ }^{11} \mathrm{GC}-\mathrm{MS}$ (gas chromatography-mass spectrometry), ${ }^{12-15}$ and electrochemical analysis. ${ }^{16-18}$ However, all these methods present at least one of the following limitations: low sensitivity, limited selectivity, non-portability, difficulties in real-time monitoring and 'false positive' readings. The main antidote in poisoning by organophosphate is a very fast pharmacological treat-

*For correspondence
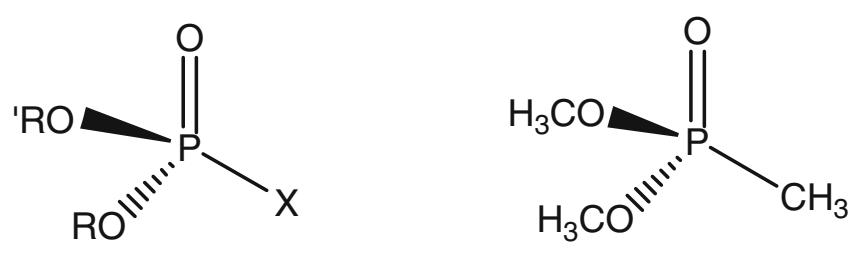

DMMP

Figure 1. General formula of an organophosphate $\left(R / R^{\prime}=\right.$ alkyl groups, $\mathrm{X}=$ halogen) (left) and dimethylmethylphosphonate (DMMP) (right).

ment based on the use of certain oximes (e.g., pralidoxime and obidoxime chloride), ${ }^{19,20}$ which due to the presence of the basic oxime group, promote the hydrolysis of phosphodiesteric bond. This mechanism is supported by 'basic activation', in particular by formation of 'supernucleophilic species' -NO-, that reacts with phosphodiesteric groups restoring the active site of AChE. This mechanism is irreversible and leads to wastage of oxime.

The ability of phosphoryl groups to accept hydrogen bond is well-known, ${ }^{21,22}$ but to date the exploitation of this group for hydrogen bond-mediated recognition of CWAs remains under-exploited. Very recently, Gale reported on the complexation of Soman (an extremely toxic chemical warfare agent), by a series of diindolylurea-based receptors. ${ }^{23}{ }^{1} \mathrm{H}$ and ${ }^{31} \mathrm{P}$ NMR titrations have shown that these hydrogen-bond donating receptors bind Soman in organic solution. Here, we present the ability of three different oximes to bind a well-known nerve agents simulant (DMMP) in 
solution via hydrogen bond, without activation in basic condition.

\section{Experimental}

\subsection{General}

The NMR experiments were carried out at $27^{\circ} \mathrm{C}$ on a Varian UNITY Inova $500 \mathrm{MHz}$ spectrometer $\left({ }^{1} \mathrm{H}\right.$ NMR at $499.88 \mathrm{MHz},{ }^{13} \mathrm{C} \mathrm{NMR}$ at $125.7 \mathrm{MHz}$ in $\mathrm{CDCl}_{3}$ ) equipped with pulse field gradient module ( $Z$ axis) and a tunable $5 \mathrm{~mm}$ Varian inverse detection probe (ID-PFG). UV-VIS spectra were measured on JascoV630 spectrometer using solution in $\mathrm{CH}_{3} \mathrm{CN}$. All chemicals were of reagent grade and were used without further purification. Synthesis of oximes $\mathbf{1}^{24}$ and $\mathbf{2}^{25}$ and compound $\mathbf{5}^{26-28}$ are in accordance with literature procedures.

2.1a Synthesis of 4-phtalimidododeciyloxy-benzaldhyde (6): A solution in dry acetonitrile $(10 \mathrm{~mL})$ containing $200 \mathrm{mg}(1.64 \mathrm{mmol})$ of $4,2.3 \mathrm{~g}(16.91 \mathrm{mmol})$ of anhydrous $\mathrm{K}_{2} \mathrm{CO}_{3}$ and $625 \mathrm{mg}(1.8 \mathrm{mmol})$ of 5 was stirred at reflux for $36 \mathrm{~h}$. The solvent was removed under reduced pressure, and the residue was dissolved in $\mathrm{CH}_{2} \mathrm{Cl}_{2}$. The organic phase was washed with water (thrice), and the solvent was evaporated to afford an oil. Crystallization by $\mathrm{CH}_{2} \mathrm{Cl}_{2} /$ hexane yielded the pure compound 6 (isolated yield 62\%). ${ }^{1} \mathrm{H} \mathrm{NMR}\left(500 \mathrm{MHz}, \mathrm{CDCl}_{3}\right)$, $\delta=9.87(\mathrm{~s}, 1 \mathrm{H}), 7.83(\mathrm{dd}, 2 \mathrm{H}), 7.81(\mathrm{~d}, J=8.5 \mathrm{~Hz}$, 2H), $7.69(\mathrm{~m}, 2 \mathrm{H}), 6.98(\mathrm{~d}, J=8.5 \mathrm{~Hz}, 2 \mathrm{H}), 4.02$ $(\mathrm{t}, J=6.5 \mathrm{~Hz}, 2 \mathrm{H}), 3.66(\mathrm{t}, J=7.0 \mathrm{~Hz}, 2 \mathrm{H}), 1.80(\mathrm{~m}$, $2 \mathrm{H}), 1.66(\mathrm{~m}, 2 \mathrm{H}), 1.44(\mathrm{~m}, 2 \mathrm{H}), 1.28(\mathrm{~m}, 14 \mathrm{H}) .{ }^{13} \mathrm{C}$ NMR (DMSO 125 MHz) $\delta$ 26.3, 27.1, 28.2, 29.3, 29.5 $(\times 2), 29.7,30.0(\times 3), 38.1,69.6,115.8,123.9,130.5$, 132.0, 132.2, 135.0, 164.4, 168.5, 192.1 ppm. Elemental Analysis Calcd. (\%) for $\mathrm{C}_{27} \mathrm{H}_{33} \mathrm{NO}_{4}: \mathrm{C}, 74.45 ; \mathrm{H}$, 7.64. Found: C, 74.43; H, 7.61.

2.1b Synthesis of 4-phtalimidododecyloxy-benzaldoxime (3): To a solution of $100 \mathrm{mg}(0.23 \mathrm{mmol})$ of aldehyde 6 in $10 \mathrm{~mL}$ of absolute ethanol, a solution of hydroxylamine chloride (32 $\mathrm{mg}, 0.46 \mathrm{mmol}$ ) and $\mathrm{NaOH}$ (18.3 mg, $0.46 \mathrm{mmol}$ ) in $5 \mathrm{~mL}$ of $\mathrm{H}_{2} \mathrm{O}$ was added. The mixture was stirred at room temperature for $7 \mathrm{~h}$. Acetic acid was added to the reaction mixture to $\mathrm{pH} 6$ cooling with an ice bath for $1 \mathrm{~h}$. The white solid formed was filtered and washed with a mixture of water/acetic acid (10:1) to afford the desired compound $\mathbf{3}$ (isolated yield $77 \%) .{ }^{1} \mathrm{H}$ NMR $\left(500 \mathrm{MHz}, \mathrm{CDCl}_{3}\right), \delta=8.07(\mathrm{~s}, 1 \mathrm{H})$, $7.84(\mathrm{dd}, 2 \mathrm{H}), 7.71(\mathrm{dd}, 2 \mathrm{H}), 7.49(\mathrm{~d}, J=8.5 \mathrm{~Hz}$, 2H), 7.04 (s br, 1H), 6.89 (d, $J=8.5 \mathrm{~Hz}, 2 \mathrm{H}), 3.98$ $(\mathrm{t}, J=6.5 \mathrm{~Hz}, 2 \mathrm{H}), 3.68(\mathrm{t}, J=7.0 \mathrm{~Hz}, 2 \mathrm{H}), 1.78$ $(\mathrm{m}, 2 \mathrm{H}), 1.66(\mathrm{~m}, 2 \mathrm{H}), 1.44(\mathrm{~m}, 2 \mathrm{H}), 1.28(\mathrm{~m}, 14 \mathrm{H})$. Elemental Analysis Calcd. (\%) for $\mathrm{C}_{27} \mathrm{H}_{34} \mathrm{~N}_{2} \mathrm{O}_{4}$ : C, 71.97; H, 7.61. Found: C, 71.91; H, 7.64.

\section{Results and discussion}

Oximes 1 and 2 reported in figure 2 were synthesized following the literature procedures, ${ }^{24,25}$ while $\mathbf{3}$ was prepared according to the reactions showen in scheme 1.

Introduction of a dodecylphtalimidic $\operatorname{arm}^{26-28}$ in the aromatic ring of $\mathbf{1}$ leads to oxime $\mathbf{3}$. This functionalization can be exploited to anchor the oxime 3 onto a solid support, ${ }^{29}$ (conversion of the phthalimido moiety into an amino group by treatment with hydrazine, under standard Gabriel conditions), achieving a 'device' for the organophosphate detection. The target 4-phtalimidododecyloxy-benzaldoxime 3 (scheme 1) was synthesized in two steps starting from 4-hydroxybenzaldehyde 4.

Compound 4 was treated in acetonitrile using an excess of potassium carbonate with $\mathrm{N}$-(12-bromododecyl)phthalimide $\mathbf{5}^{26-28}$ to yield the phtalimidododecyloxy derivative 6 (isolated yield 62\%). Conversion of aldehyde into an oxime group by treatment with hydoxylamine hydrochloride and sodium hydroxide yielded the oxime 3 (isolated yield $77 \%$ ). Compounds 3 and 6 were characterized by ${ }^{1} \mathrm{H}$ - and ${ }^{13} \mathrm{C}$ NMR spectroscopy, as well as by elementary analysis (see Electronic supplementary information).
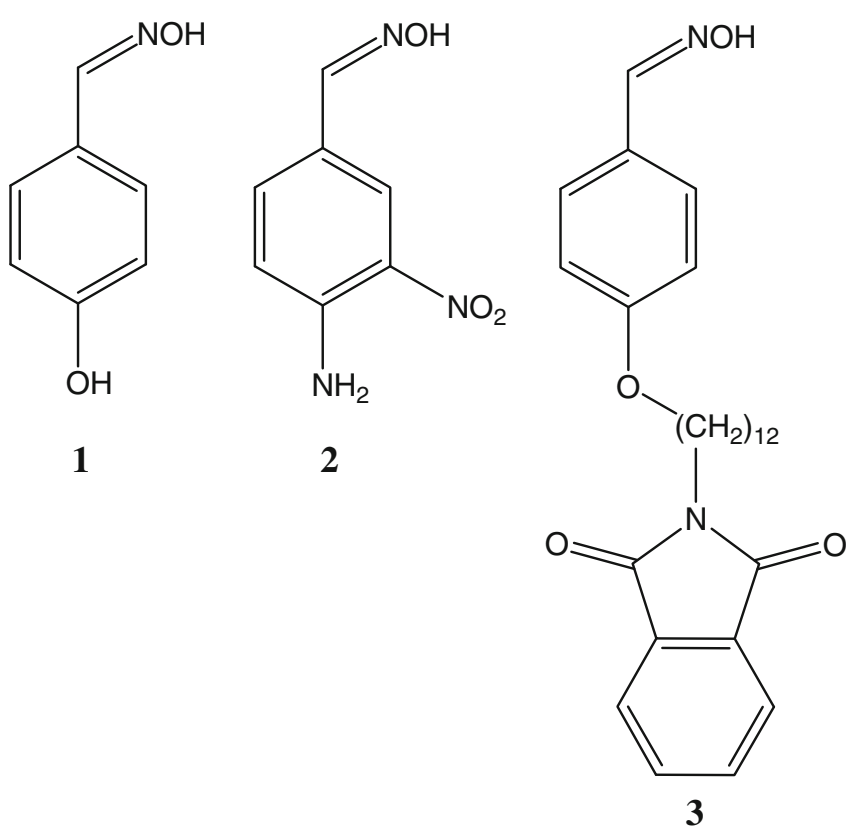

Figure 2. Chemical structure of oximes 1-3. 

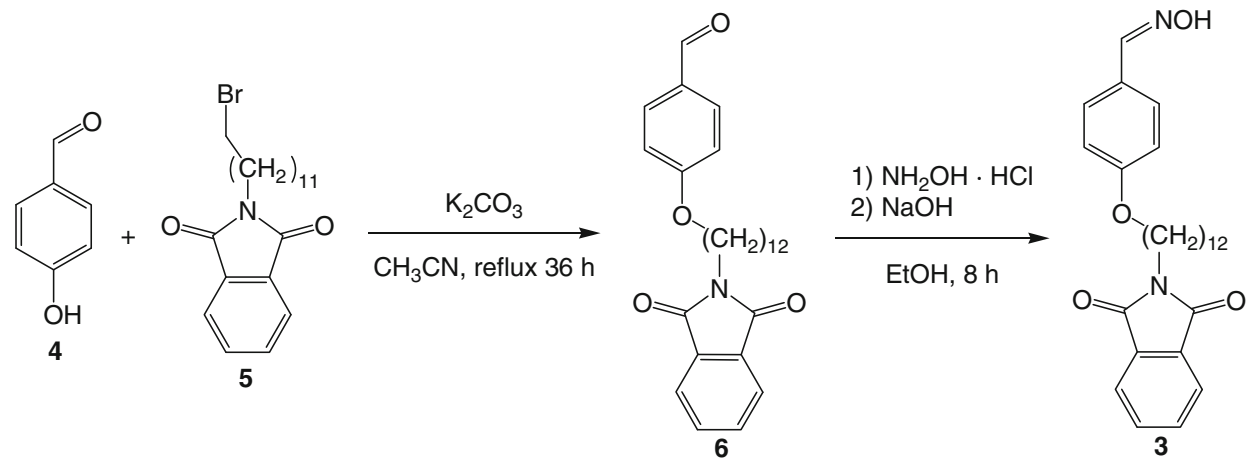

Scheme 1. Synthesis of 4-phtalimido-dodecyloxy-benzaldoxime 3 .

The ability of oximes 1-3 to recognize and bind organophosphorous derivatives was studied by UVVis spectroscopy using DMMP as simulant of nerve agents. ${ }^{30-32}$ Figure 3 shows a typical UV/Vis titration experiment between oxime 1 and DMMP.

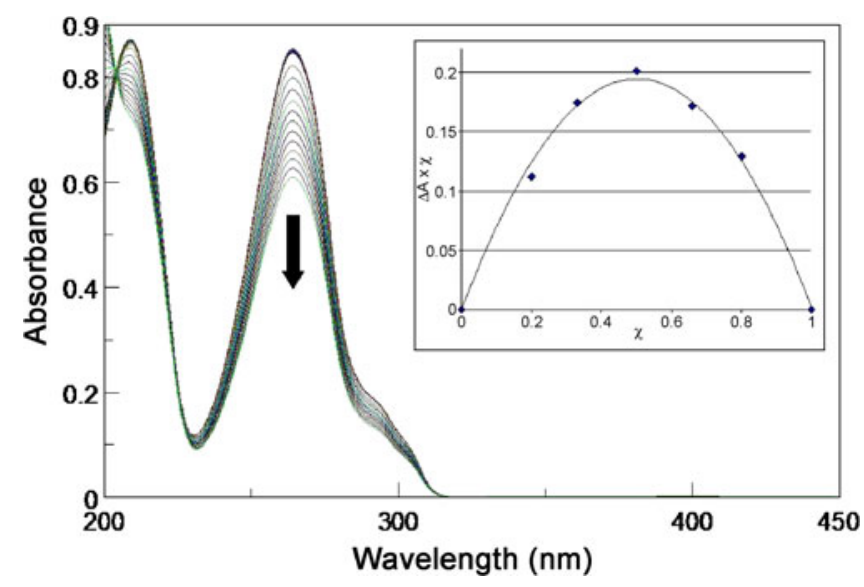

Figure 3. UV/Vis titration experiment of oxime 1 upon addition of increasing amounts of DMMP $\left(1.5 \cdot 10^{-5}\right.$ to $1.7 \cdot 10^{-3} \mathrm{M}$ ) in $\mathrm{CH}_{3} \mathrm{CN}$ at $25^{\circ} \mathrm{C}$. The inset displays the corresponding job's plot.
Progressive decreasing of absorbance at $264 \mathrm{~nm}$, upon addition of increasing amounts of DMMP, is relative to $\pi-\pi^{*}$ transition suggesting an interaction between oxime group and DMMP. ${ }^{33}$ Free energy $\Delta G^{\circ}$ calculated from the binding constant of the complex 1 $\subset \operatorname{DMMP}\left(K=2.0 \times 10^{3} \mathrm{M}^{-1}\right)^{34-39}$ is $-4.49 \mathrm{Kcal} / \mathrm{mol}$, in good agreement with an interaction based on the formation of an hydrogen bond (see ESI 4-6). A similar behaviour was found with oximes $\mathbf{2}$ and 3; UV/Vis titration experiments between oximes $\mathbf{2}$ and $\mathbf{3}$ with DMMP are reported in figure 4.

Binding constant value for the complex $\mathbf{2} \subset$ DMMP is $K=1.0 \times 10^{2} \mathrm{M}^{-1}$ and the associated $\Delta G^{\circ}$ is $-2.72 \mathrm{Kcal} / \mathrm{mol}$, while affinity value of the complex 3 $\subset$ DMMP is $K=2.9 \times 10^{3} \mathrm{M}^{-1}$ with a related $\Delta G^{\circ}$ of $-4.71 \mathrm{Kcal} / \mathrm{mol}$. Also, in these cases, the energy values clearly indicate that a weak interaction is involved. Differences between the binding constant values deserve a comment: it is clear that the presence of the strong electron-acceptor group $\mathrm{NO}_{2}$ in $\mathbf{2}$ reduces the binding energy with DMMP, while oximes $\mathbf{1}$ and $\mathbf{3}$ show a comparable energy probably due to a similar electronic effect.
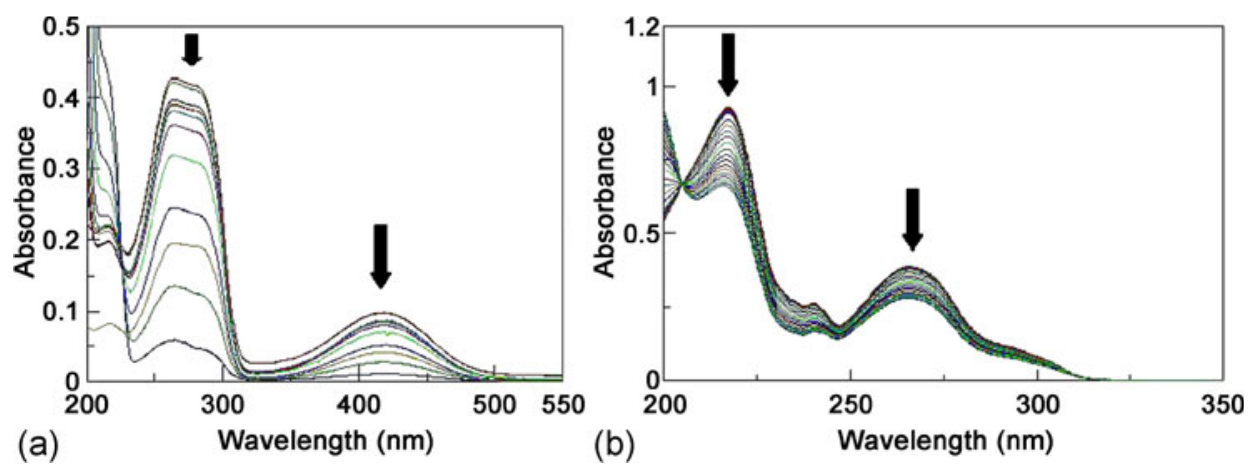

Figure 4. UV/Vis titration experiments of (a) oxime $\mathbf{2}$ and (b) oxime $\mathbf{3}$ upon addition of increasing amounts of DMMP in $\mathrm{CH}_{3} \mathrm{CN}$ at $25^{\circ} \mathrm{C}$. 
Hence, to confirm this hypothesis, ${ }^{1} \mathrm{H}$ - and ${ }^{31} \mathrm{P}-\mathrm{NMR}$ titration experiments were performed. Figure 5 shows the downfield shift of the proton of $-\mathrm{NOH}$ group of the oxime 2 upon the addition of 1 equivalent of DMMP in $\mathrm{CD}_{3} \mathrm{CN}$.

A similar experiment was carried out in DMSO- $d_{6}$ but no chemical shift changes were observed after the addition of 1 equivalent of DMMP (see ESI 10), indicating that hydrogen bonding between 2 and DMMP in DMSO is precluded by the competition of the strong polar solvent.

Furthermore, ${ }^{31} \mathrm{P}$ NMR titration of DMMP with different aliquots of oxime 2 (figure 6) shows a downfield shift of the phosphorous signal due to the interaction with the hydroxyl group of the oxime.

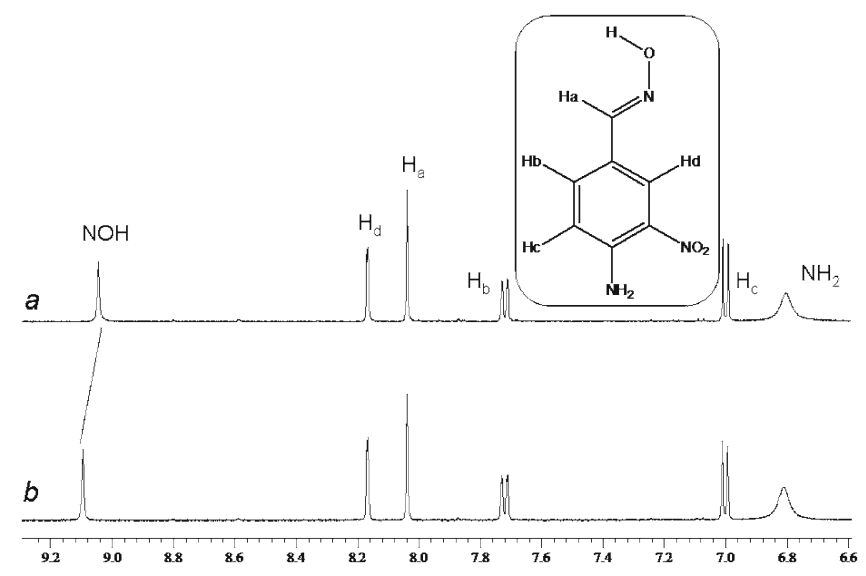

Figure 5. (a) ${ }^{1} \mathrm{H}$ NMR spectra of $2\left(1 \times 10^{-3} \mathrm{M}\right.$ in $\mathrm{CD}_{3} \mathrm{CN}$ ), (b) ${ }^{1} \mathrm{H}$ NMR spectra of 2 with 1 equivalent of DMMP in $\mathrm{CD}_{3} \mathrm{CN}$.

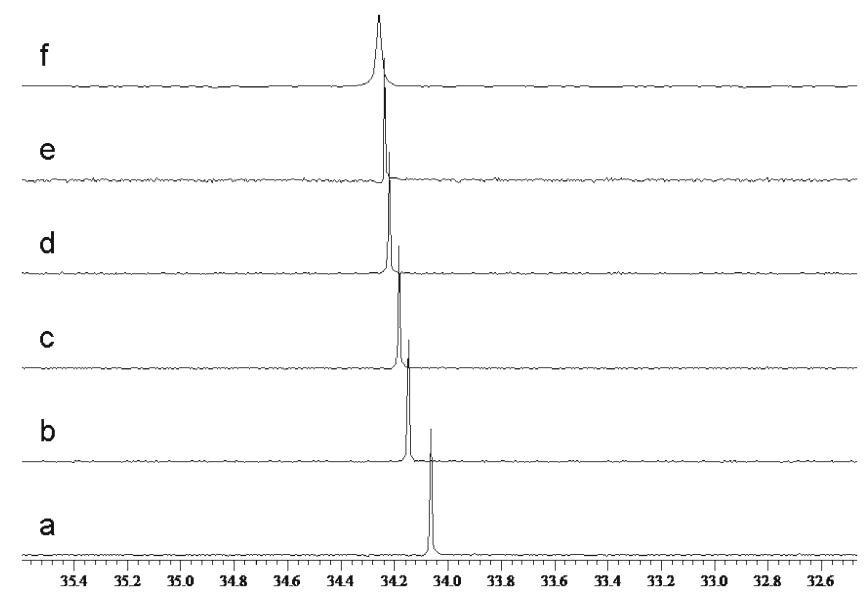

Figure 6. Selected region of the spectrum in a typical ${ }^{31} \mathrm{P}$ NMR titration of DMMP with oxime 2 in $\mathrm{CD}_{3} \mathrm{CN}$. Constant concentration of DMMP $\left(1 \times 10^{-3} \mathrm{M}\right)$ with addition of various concentrations ( 0 to $\left.2 \times 10^{-3} \mathrm{M}\right)$ of 2 . (a) DMMP; (b) $[\mathrm{DMMP}] /[2] 4: 1 ;$ (c) $[\mathrm{DMMP}] /[2] 2: 1 ;$ (d) [DMMP]/[2] $1: 1$ (e) [DMMP]/[2] $1: 1.5 ;$ (f) [DMMP]/[2] $1: 2$.

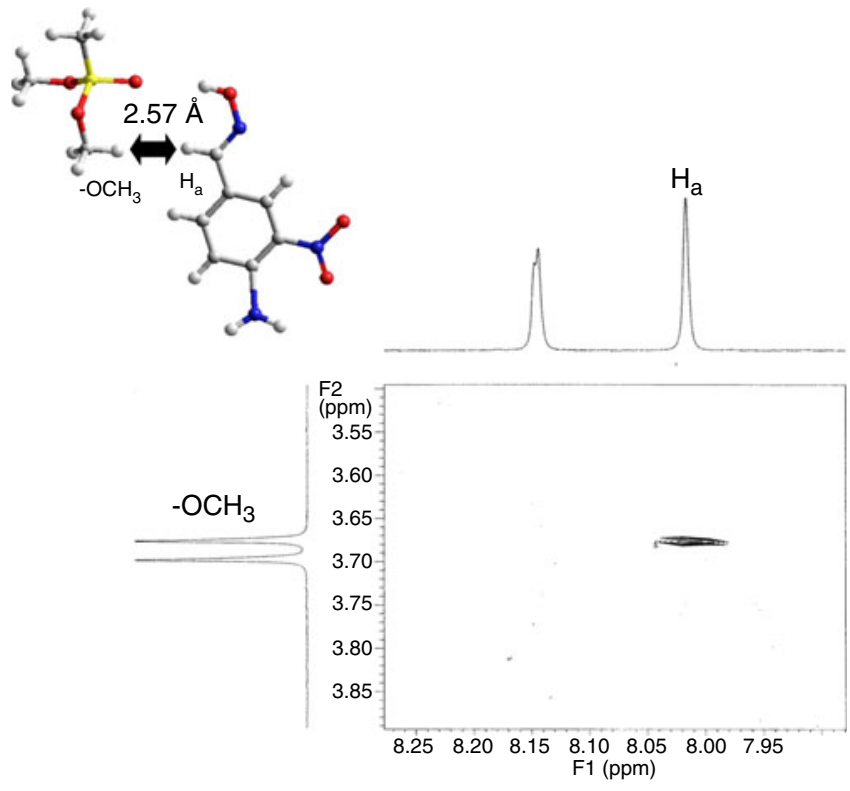

Figure 7. Details of T-ROESY of the complex $2 \subset$ DMMP $\left(1 \times 10^{-3} \mathrm{M}\right.$ in $\left.\mathrm{CD}_{3} \mathrm{CN}\right)$. (Optimized structure of the complex $2 \subset$ DMMP; HyperChem 7.5, Amber).

In addition, T-ROESY experiment of the complex $2 \subset$ DMMP reveals an Overhauser contact between the hydrogen of the imine group and the $-\mathrm{OCH}_{3}$ group of the DMMP (figure 7); moreover, molecular modelling supports the hydrogen bonding interaction between the hydroxymethyl group of DMMP and the imine hydrogen of 2 (calculated distance is $2.57 \AA$, figure 7).

\section{Conclusion}

In summary, we reported the ability of three oximes to bind the simulant nerve agent DMMP in solution by hydrogen bond interaction. Pertinent binding constant values of the complexes of oximes 1-3 with DMMP were determined by UV-Vis titrations, while ${ }^{1} \mathrm{H}-,{ }^{31} \mathrm{P}-$ NMR titrations and T-ROESY experiments provide good evidences of the hydrogen bond interaction. In oxime 3, the phtalimido group can be converted into amino group, allowing to anchor the molecule onto a solid support via nucleophilic attack. The non-covalent interactions of this systems with DMMP are at the basis for the realization of reversible detectors of nerve agent simulants in solution and also on solid supports.

\section{Supplementary Information}

The electronic supporting information can be seen in www.ias.ac.in/chemsci. 


\section{Acknowledgement}

Authors thank Università di Catania for financial support.

\section{References}

1. Gilmore J S 2003 RAND Reports vol. 5

2. Walt D R and Franz D R 2000 Anal. Chem. 72738 A

3. Hartgraves S L and Murphy M R 1992 In Chemical warfare agents (ed.) S M Somani (San Diego, CA: Academic Press) p. 125

4. Yang C M, Dwyer T M and Farley J M 1991 Fundamental Appl. Toxicol. 1734

5. Lee Y, Choi D, Koh W and Kim B 2009 Sensors Actuat. B-Chem. 137209

6. Karnati C, Du H, Ji H, Xu X, Lvov Y, Mulchandani A, Mulchandani P and Chen W 2007, Biosens. Bioelectron. 222636

7. Turdean G L, Popescu I C, Oniciu L and Thevenot D R 2002 J. Enzym. Inhib. Med. Chem. 17107

8. Andreescu S, Avramescu A, Bala C, Magearu V and Marty J 2002 Anal. Bioanal. Chem. 37439

9. Upadhyayula K K 2012 Anal. Chim. Acta 7151

10. Kumar V and Kaushik M P 2011 Analyst 1365151

11. Zhang J, Luo A, Liu P, Wei S, Wang G and Wei S 2009 Anal. Sci. 25511

12. Richardson D D and Caruso J A 2007 Anal. Bioanal. Chem. 388809

13. Terzic O, Swahn I, Cretu G, Palit M and Mallard G 2012 J. Chromatogr. A $\mathbf{1 2 2 5} 182$

14. Alekseenko S S 2012 J. Anal. Chem. 6782

15. Popiel S and Sankowska M 2011 J. Chromatogr. A 1218 8457

16. Galezowska A, Sikora T, Istamboulie G, Trojanowicz M, Polec I, Nunes G S, Noguer T and Marty J 2008 Sensor Mater. 20299

17. Liu G, Wang J, Barry R, Petersen C, Timchalk C, Gassman P L and Lin Y 2008 Chem. Eur. J. 14 9951

18. Chen A, Du D and Lin Y 2012 Environ. Sci. Technol. 46 1828

19. Zhang Y, Miyata T, Wu Z, Wu G and Xie L 2007 Arch. Toxicol. 81785

20. Kassa J, Karasova J Z, Sepsova V, Caisberger F and Bajgar J 2011 Int. J. Toxicol. 30562
21. Modro A M and Modro T A 1999 Can. J. Chem. 77890

22. Gramstad T and Fuglevik W J 1965 Spectrochim. Acta 21503

23. Sambrook M R, Hiscock J R, Cook A, Green A C, Holden I, Vincent J C and Gale P A 2012 Chem. Commun. 48, 5605

24. Huang N, Chern Y, Fang J, Lin C, Chen W and Lin Y 2007 J. Nat. Prod. 70571

25. Wallace K, Morey J, Vincent L M and Anslyn E V 2005 New J. Chem. 291469

26. Pfammatter M J and Siljegovic V 2001 Helv. Chim. Acta 84678

27. Pappalardo S, Villari V, Slovak S, Cohen Y, Gattuso G, Notti A, Pappalardo A, Pisagatti I and Parisi M F 2007 Chem. Eur. J. 138164

28. Cristaldi D A, Fragalà I., Pappalardo A, Toscano R M, Ballistreri F P, Tomaselli G A and Gulino A 2012 J. Mater. Chem. 22675

29. La Paglia Fragola V, Lupo F, Pappalardo A, Trusso Sfrazzetto G, Toscano R M, Ballistreri F P, Tomaselli G A and Gulino A 2012 J. Mater. Chem. 2220561

30. Du X, Wang Z, Huang J, Tao S, Tang X and Jiang Y 2009 J. Mat. Sci. 445872

31. Panayotov D A and Morris J R 2009 J. Phys. Chem. C 11315684

32. Panayotov D A and Morris J R 2009 Langmuir 253652

33. 'Diluition effect' was excluded by measurement of absorbance of 1 in the same concentration values in absence of DMMP.

34. Calculated by HYPERQUAD 2006 (version 3.1.60): Gans P, Sabatini A and Vacca A 1996 Talanta 431739

35. Ballistreri F P, Pappalardo A, Toscano R M, Tomaselli A and Trusso Sfrazzetto G 2010 Eur. J. Org. Chem. 20 3806

36. Ballistreri F P, Condorelli G G, Fragalà I, Motta A, Pappalardo A, Tomaselli G A, Tudisco C and Trusso Sfrazzetto G 2011 Eur. J. Inorg. Chem. 20112124

37. Amato M E, Ballistreri F P, D'Agata S, Pappalardo A, Tomaselli G A, Toscano R M and Trusso Sfrazzetto G 2011 Eur. J. Org. Chem. 20115674

38. Pappalardo A, Amato M E, Ballistreri F P, Tomaselli G A, Toscano R M and Trusso Sfrazzetto G 2012 J. Org. Chem. 777684

39. Pappalardo A, Ballistreri F P, Li Destri G, Mineo P G, Tomaselli G A, Toscano R M and Trusso Sfrazzetto G 2012 Macromolecules 457549 